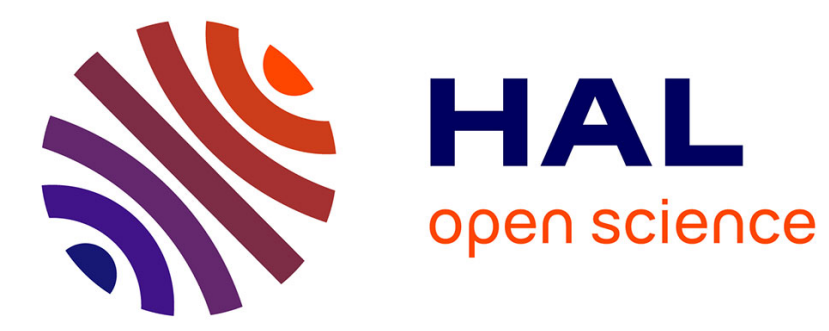

\title{
Synthetic-resin-free wood panel adhesives from mixed low molecular mass lignin and tannin
}

\author{
H. R. Mansouri, P. Navarrete, A. Pizzi, S. Tapin-Lingua, B.
}

Benjelloun-Mlayah, H. Pasch, S. Rigolet

\section{- To cite this version:}

H. R. Mansouri, P. Navarrete, A. Pizzi, S. Tapin-Lingua, B. Benjelloun-Mlayah, et al.. Syntheticresin-free wood panel adhesives from mixed low molecular mass lignin and tannin. European Journal of Wood and Wood Products, 2010, 69 (2), pp.221-229. 10.1007/s00107-010-0423-0 . hal-00594484

\section{HAL Id: hal-00594484 \\ https://hal.science/hal-00594484}

Submitted on 20 May 2011

HAL is a multi-disciplinary open access archive for the deposit and dissemination of scientific research documents, whether they are published or not. The documents may come from teaching and research institutions in France or abroad, or from public or private research centers.
L'archive ouverte pluridisciplinaire HAL, est destinée au dépôt et à la diffusion de documents scientifiques de niveau recherche, publiés ou non, émanant des établissements d'enseignement et de recherche français ou étrangers, des laboratoires publics ou privés. 


\title{
SYNTHETIC-RESIN-FREE WOOD PANEL ADHESIVES FROM MIXED LOW MOLECULAR MASS LIGNIN AND TANNIN
}

H.R.Mansouri, P.Navarrete, A.Pizzi, S.Tapin-Lingua, B.Benjelloun-Mlayah, H.Pasch, S.Rigolet

H.R.Mansouri, P.Navarrete, A.Pizzi $(\bowtie)$

ENSTIB-LERMAB, Nancy University, Epinal, France

S.Tapin-Lingua

FCBA, Centre Technologique Forêt, Cellulose, Bois, Ameublement, Grenoble, France

B.Benjelloun-Mlayah

CIMV, Compagnie Industrielle de la Matiere Vegetale, Levallois-Perret, France

S.Rigolet

Matériaux à Porosité Contrôlée, Institut de Science des Matériaux de Mulhouse (IS2M) - LRC CNRS 7228 - University of Haute Alsace, Mulhouse, France

H.Pasch, Deutsches Kunststoff-Institut, Darmstadt, Germany

\begin{abstract}
Mixed interior wood panel tannin adhesive formulations were developed in which lignin is in considerable proportion, $50 \%$, of the wood panel binder and in which no "fortification" with synthetic resins, such as isocyanates and phenol-formaldehyde resins as used in the past, was necessary to obtain results satisfying relevant standards. A low molecular mass lignin obtained industrially by formic acid/acetic acid pulping of wheat straw was used. Environment-friendly, non-toxic polymeric materials of natural origin constitute up to $94 \%$ of the total panel binder. The wood panel itself is constituted of $99.5 \%$ natural materials, the $0.5 \%$ balance being composed of glyoxal, a non toxic and non volatile aldehyde, and of hexamine already accepted as a non-formaldehyde-yielding compound when in presence of condensed tannin. Both particleboard and two types of plywood were shown to pass the relevant interior standards with such adhesive formulations. Moreover, the much cheaper nonpurified organosolv lignin showed the same level of results as the more expensive purified type.
\end{abstract}

\section{Kunstharzfreie Klebstoffe für Holzwerkstoffe aus niedermolekularem Lignin und Tannin}

\section{Zusammenfassung}

Es wurden verschiedene Tannin-Klebstoff-Rezepturen mit einem hohen Ligninanteil von 50\% für plattenförmige Holzwerkstoffe für den Innenbereich entwickelt. Dabei konnte auf eine „Verstärkung“ mit Kunstharzen, wie zum Beispiel Isocyanaten und Phenolformaldehyd, wie sie bisher zur Erfüllung der Anforderung relevanter Normen erforderlich war, verzichtet werden. Verwendet wurde ein niedermolekulares Lignin, das industriell durch Ameisensäure/Essigsäureaufschluss von Weizenstroh gewonnen wurde. Umweltfreundliche, ungiftige polymerische Stoffe natürlichen Ursprungs machen bis zu 94\% des gesamten Bindemittels aus. Die Holzplatte selber besteht zu 99,5\% aus natürlichen Materialien und zu 0,5\% aus Glyoxal, einem nicht toxischen und nicht flüchtigen Aldehyd, sowie aus Hexamin, das in Verbindung mit kondensiertem Tannin als nicht Formaldehyd emittierende Substanz gilt. Es wurde gezeigt, dass sowohl eine Spanplatte als auch zwei Sperrholzarten, die unter 
Verwendung dieser Rezepturen hergestellt wurden, entsprechende Normen für Platten zur Verwendung im Innenbereich erfüllten. Zudem führte das wesentlich billigere, ungereinigte Organosolv-Lignin zu gleichen Ergebnissen wie der viel teurere, gereinigte Typ.

\section{INTRODUCTION}

Biocomposites are and have been an area of growing interest and a subject of active research for quite some time now. This is due to both environmental concerns as well as the foreseen future scarcity of oil and oil-derived products. One class of composites in which natural origin resins already have commercial/industrial impact is in the field of rigid wood panels, such as particleboard. Natural origin resins are already used commercially for the last 30 years for these wood panels, and their use is still growing, although still relatively slowly (Pizzi 2006). In such an application, the binder is never more than $10 \%$ by weight of the whole composite panel. This is sufficient to stay in line with the performance and costs required by the wood panel industry and their respective product standards.

The main natural resins used as wood panel binders are vegetal tannin adhesives, lignin adhesives and more recently also soy protein adhesives (Pizzi 2006). Of these tannin-based adhesives have been commercial the longest, since 1971. They have the advantage of not needing any reinforcement with an oil-derived synthetic resin of some kind in comparison to the other two types (Pizzi 2006). This is, however, still the case for the already commercial use of lignin (Lei and Pizzi 2008; Pizzi and Stephanou 1993a,b; El Mansouri et al. 2007) and soy binders (Lorenz et al. 2006; Wescott et al. 2006; Amaral-Labat et al. 2008; Pizzi 2006), where either phenol-formaldehyde or very often PMDI (polymeric isocyanate) is till needed in amounts between $20 \%$ and $40 \%$ of the total resin to satisfy the requirements of relevant board standards.

The use of synthetic resins limits somewhat the environmental attractiveness of such adhesives based on natural materials, while the use of tannin alone is limited at present by the relatively limited supply of these materials (Pizzi 2006). Thus, the aim is to prepare an adhesive based on materials of natural origin, satisfying international standards for both performance and emission, which does not emit or even better does not contain any formaldehyde, the composition of which does not include any synthetic resins, and which uses cheap and widely available materials. This will render wood panel adhesives based on natural materials much more accepted both economically and environmentally.

This paper deals with the preparation of lower-cost wood panel adhesives of good performance based on natural materials and without fortification by any synthetic resins.

\section{EXPERIMENTAL}

\section{Preparation of glyoxalated lignin resin}

The lignin used was a low molecular mass lignin obtained industrially as a by-product of pulp and paper production from wheat straw by an acetic acid-based organosolv process US patent 7,402,224 (Avignon and Delmas US patent 7,402,224 -2000). Two types of lignin were used, one washed and purified and the other prior to washing. In this article, the second type of lignin is called "impure" lignin. These two lignins were supplied by the industrial manufacturer, CIMV (Compagnie Industrielle de la Matiere Vegetale, Reims factory, France). The characteristics of the two specimens were determined by the FCBA (Table 1) and by CIMV (Table 2). 295 parts by mass of this lignin powder ( $96 \%$ solid) were slowly added to 477 parts water while sodium hydroxide solution (30\%) was added from time to time thus keeping the $\mathrm{pH}$ of the solution between 12 and 12.5 for better dissolution of the lignin powder which was also facilitated by vigorous stirring with an overhead stirrer. A total of 141 parts by mass of $30 \%$ sodium hydroxide water solution was added which resulted in a final $\mathrm{pH}$ close to 12.5 . 
A 2 litre flat bottom flask equipped with condenser, thermometer and magnetic stirrer bar was charged with the above solution and heated to $58^{\circ} \mathrm{C} .87 .5$ parts by mass glyoxal $(40 \%$ in water) were added and the lignin solution was then continuously stirred with a magnetic stirrer/hot plate for 8 hours. The solids content for the glyoxalated lignin was around $31 \%$. Glyoxal is a non-volatile non-toxic aldehyde that has been tested in lignin (El Mansouri et al. 2007; Lorenz et al. 2006) and tannin adhesives (Ballerini et al. 2005) and other adhesives (Amaral-Labat et al. 2008) for application to wood panels such as particleboard. Glyoxal is a non-toxic aldehyde (LD50 rat $\geq 2960 \mathrm{mg} / \mathrm{kg}$; LD50 mouse $\geq 1280$ $\mathrm{mg} / \mathrm{kg}$ ) (NIOSH 2000), non-volatile but less reactive than formaldehyde which is toxic (LD50 rat $\geq$ $100 \mathrm{mg} / \mathrm{kg} ;$ LD50 mouse $\geq 42 \mathrm{mg} / \mathrm{kg}$ ) (NTIS).

\section{Tannin and final resin}

Mimosa tannin extract (ex Tanzania, supplied by Silva, S.Michele Mondovi', Italy) with a Stiasny value of 92.2 (Stiasny 1905a, b; Hillis and Urbach 1959; Suomi-Lindberg 1985) was used. The tannin solution in water was prepared at $45 \%$ concentration, and its $\mathrm{pH}$ was adjusted to 10.4 with $\mathrm{NaOH} 33 \%$ water solution. The high $\mathrm{pH}$ was chosen as the hardener used performs best at such a $\mathrm{pH}$ (Pichelin et al. 2006, Hillis and Urbach 1959, Pizzi 1978; Theis and Grohe 2002). Hexamine was dissolved in water to form a $30 \%$ solution. It was added to the tannin extract solution on the basis of $5 \%$ hexamine solids on tannin extract solids to which then the glyoxalated lignin solution was added to obtain resin solids to resin solids proportion of tannin:glyoxaleted lignin of 50:50 by weight. Hexamine hardener is now accepted by JIS A5908 as no formaldehyde source in presence of a polyflavonoid condensed tannin (Pichelin et al. 2006; Kamoun and Pizzi, 2000a, b; Kamoun et al. 2003).

The total amount of natural material on dry resin solids was almost $94 \%$ and the adhesive so prepared did not contain any synthetic resins.

\section{Wood panels (particleboard and plywood) manufacture and testing}

Duplicate one layer laboratory particleboard of $350 \times 300 \times 14 \mathrm{~mm}^{3}$ dimension were prepared using a mixture of core particles of beech (Fagus sylvatica) and Norway spruce (Picea abies) wood particles at $28 \mathrm{~kg} / \mathrm{cm}^{2}$ maximum pressure and $190^{\circ}-195^{\circ} \mathrm{C}$ press temperature. The wood particles prior to resin addition had a moisture content of $2 \%$. The resin solids load on dry wood was maintained at $10 \%$ of the total mix of tannin + glyoxalated lignin. The total pressing time was maintained at 7.5 minutes. All particleboards were tested for dry internal bond (IB) strength. The IB strength test is a relevant international standard test (EN 312:1995) done on five board specimens and a tension test perpendicular to the plane of the board. Thus, each IB and panel density result in the tables is the average of ten specimens. The panel density reported in the tables is the average of the density of the series of specimens for each series of panels.

Three ply triplicate wood panels of $500 \times 300 \times 14 \mathrm{~mm}^{3}$ and $400 \times 400 \times 6 \mathrm{~mm}^{3}$ dimension were prepared. The former was composed of pine wood (Pinus sylvestris) veneers of respectively $3.5 \mathrm{~mm}$ and $7 \mathrm{~mm}$ thickness for the two lower plies and an oak (Quercus spp.) veneer of $3.5 \mathrm{~mm}$ thickness for the upper veneer. The assembly was then $3.5 \times 7 \times 3.5 \mathrm{~mm}^{3}$ for a total of $14 \mathrm{~mm}$ total plywood thickness. These were panels apt for floor covering. The latter were of $2 \mathrm{~mm}$ thick beech (Fagus sylvatica) veneers. The following glue mix was used in parts by weight: a solution of the Tannin/Hexamine + Glyoxalated lignin resins described above in proportion $50 / 50$ by dry weight, at $\mathrm{pH}=10.0$, to which $38 \%$ of 200 mesh olive stone flour on total resin solids was added as filler.

The glue spread used was $380 \mathrm{~g} / \mathrm{m}^{2}$ double glue line, press temperature was $130^{\circ} \mathrm{C}$, pressure was 15 $\mathrm{kg} / \mathrm{m}^{2}$ for both types of panel. Pressing time was 5 minutes for the thicker panel type, this being rather fast, and 4 minutes for the thinner one $(1$ minute $/ \mathrm{mm}$ until the furthest glue-line from the hot platen + 2 minutes). The panels were tested for dry tensile strength according to European Standard EN314 (1993).

\section{${ }^{13}$ C CP-MAS NMR spectra}

Glyoxalated organosolv lignin resins were hardened at $105^{\circ} \mathrm{C}$ for 2 hours in an oven before being finely ground for NMR analysis. The hardened lignin resins were analyzed by solid state CP MAS ${ }^{13} \mathrm{C}$ 
NMR. Spectra were obtained on a Bruker AVANCE II $400 \mathrm{MHz}$ spectrometer at a frequency of 100.6 $\mathrm{MHz}$ and at sample spin of $12 \mathrm{kHz}$, using a recycling delay of $1 \mathrm{~s}$-depending on ${ }^{1} \mathrm{H}$ spin lattice relaxation times $\left(\mathrm{t}_{1}\right)$ estimated with the inversion-recovery pulse sequence-, a contact time of $1 \mathrm{~ms}$. Number of transients was about 15000, and the decoupling field was $78 \mathrm{kHz}$. Chemical shifts were determined relative to tetramethyl silane (TMS) used as control. The spectra were accurate to $1 \mathrm{ppm}$. The spectra were run with suppression of spinning side bands.

\section{Thermomechanical analysis (TMA)}

The hardening reaction of one resin system or glues mixes can be evaluated by TMA, studying the rigidity of a bonded wood joint as a function of the temperature. Thus, glues mixes of glyoxalated purified and non-purified lignin with tannin/hexamine were analysed by TMA. The composition of different glue mixes is given in the tables. All experiments were conducted under the same conditions: heat rate $=10^{\circ} \mathrm{C} / \mathrm{min}, 30 \mathrm{mg}$ of resin, in the temperature range of $25-250^{\circ} \mathrm{C}$. The thermo-mechanical analyzer used was a Mettler Toledo TMA40. The software used for data treatment was STARe. Deflection curves that allow MOE determination were obtained by the three-point bending TMA mode. MOE of the wood joints bonded with different resin systems gave a good indication of the final strength of the adhesive system tested.

\section{Molecular weight and molecular weight distribution}

The number average molecular mass of the two lignins studied was determined by GPC. They were obtained as 1034 and 1028 for the non-purified and purified lignin, respectively. The effluent of the industrial CIMV pilot plant in Reims, France, after washing in water was monitored at $280 \mathrm{~nm}$ with a Beckman UV detector. The column (TSKgel G3000 PWXL) was calibrated with poly(ethylene glycol) in the $138-40,000 \mathrm{~g} / \mathrm{mol}$ range. The flux of the $\mathrm{NaNO}_{3}$ solution $(0.1 \mathrm{M}$ at $\mathrm{pH} 7)$ was $0.6 \mathrm{~mL} / \mathrm{min}$, and the samples were dissolved in $\mathrm{NaNO} 3$ at a concentration of $3 \mathrm{mg} / \mathrm{mL}$. The detected signal was digitalized at a frequency of $2 \mathrm{~Hz}$, and the molecular weight distribution was calculated from the recorded signal with normal GPC calculation procedures (Pichelin et al. 2006).

Examination by MALDI-TOF (Matrix assisted laser desorption/ionisation time-of-flight) mass spectrometry showed however that GPC determination of the lignin molecular mass indicates much higher values than what is real, thus that the values of Mn from GPC result also from molecular associations as already shown for other water soluble polymers (Despres and Pizzi 2006). MALDITOF results are shown in Fig. 1 indicating that molecular masses as high as those of tetramers occur, and no more, thus lower than what was obtained by GPC. The oligomers composing of the nonpurified and purified lignin are the same and in the same proportion. Their types are listed in Table 3.

The MALDI-TOF spectra were recorded on a KRATOS Kompact MALDI AXIMA TOF 2 instrument. The irradiation source was a pulsed nitrogen laser with a wavelength of $337 \mathrm{~nm}$. The length of one laser pulse was $3 \mathrm{~ns}$. The measurements were carried out using the following conditions: polarity-positive, flight path-linear, mass-high (20 kV acceleration voltage), 100-150 pulses per spectrum. The delayed extraction technique was used applying delay times of 200-800 ns.

Sample preparation: the lignin water solution samples were dissolved in acetone $(4 \mathrm{mg} / \mathrm{mL}, 50 / 50 \%$ volume). The sample solutions were mixed with an acetone solution $(10 \mathrm{mg} / \mathrm{mL}$ in acetone) of the matrix. As the matrix 2,5-dihydroxy benzoic acid was used. For the enhancement of ion formation $\mathrm{NaCl}$ was added to the matrix $(10 \mathrm{mg} / \mathrm{ml}$ in water). The solutions of the sample and the matrix were mixed in the proportions 3 parts matrix solution +3 parts polymer solution +1 part $\mathrm{NaCl}$ solution and 0.5 to $1 \mu \mathrm{L}$ of the resulting solution mix were placed on the MALDI target. After evaporation of the solvent the MALDI target was introduced into the spectrometer. The dry droplet sample preparation method was used.

\section{Phenolic hydroxyl groups by UV spectroscopy ( $\Delta \varepsilon$ method)}

The concentrations of the various phenolic units in the lignin samples were determined by UV spectroscopy, as described by Zakis (1994). This method is based on the difference in the absorption at 300 and $360 \mathrm{~nm}$ between phenolic units in neutral and alkaline solutions. The concentration of ionizing phenol hydroxyl groups can be quantitatively evaluated by comparison of the $\Delta \varepsilon$ values of 
substances studied at certain wavelengths with the values of $\Delta \varepsilon$ of the respective model compounds presenting a free ortho position in their aromatic ring.

\section{RESULTS AND DISCUSSION}

Organosolv lignin obtained with a mixed formic and acetic acids pulping technique (Avignon and Delmas 2000) is bound to present a number of phenolic and aliphatic hydroxyl groups formylated and acetylated. The results in Table 1 confirm this by the presence of formyl and acetyl group present on mainly aliphatic but also phenolic hydroxyl groups of lignin. These aliphatic and aromatic formic and acetic ester groups are of interest as the presence of esters, even in small amounts, has been shown to accelerate the reaction and curing of phenolic/aldehyde resins (Zhao et al. 1999, Pizzi and Stephanou 1993) and this also in the case of slow curing lignin-based resins (Pizzi and Stephanou 1993 a,b).

Their presence in this type of organosolv lignin is therefore of some benefit. The proportions of acid soluble and Klason lignin shown in Table 2 indicate that in the case of both the purified and non purified wheat straw organosolv lignins the level of total lignin is high. Not much difference occurs between the two lignins, and even the values of their number average molecular mass are very similar at 1028 and $1034 \mathrm{~g} / \mathrm{mol}$. The percentage distribution of residual sugar oligomers is also similar (Table 2) to glucans and xylans from hemicelluloses and also cellulose predominating. The major difference being observed is the percentage of inorganic ashes. In this case the ashes are the cations of residual acetic and formic acid salts which derive from the precipitation and washing with a $\mathrm{NaOH}$ water solution of the residual lignin (Avignon and Delmas 2000).

A word of warning must be given on the GPC results of molecular mass. MALDI-TOF examination of the same two lignins (Fig. 1) showed that the masses of the highest oligomers are lower than what was observed by GPC, indicating that even in this case, like for other water soluble polymers, colloidal molecular associations often falsify the results of GPC mass determination (Despres and Pizzi 2006, Roux 1976). It is nonetheless of interest to observe the type and relative proportion of the oligomers existing in this organosolv lignin as listed in Table 3. From this one it can be seen that dimers and trimers of different types predominate, but that no oligomers of higher mass are present, confirming that the Mn results obtained by GPC are too high and due to association. In Table 3 the interpretation of the compounds involved are indicated as $\mathrm{G}$ for guaiacyl units, $\mathrm{S}$ for siringyl units, and $\mathrm{H}$ for phenolic units not containing methoxy groups. The linkages between them are indicated with the "classical" nomenclature (Fengel and Wegener 1983) as $\beta \mathrm{O} 4, \alpha \mathrm{O} 4, \beta \beta, \beta 5,55$ '. Thus, as an example, the G- $\beta$ O4-S and G- $\alpha \mathrm{O} 4-\mathrm{S}$ peak at $731 \mathrm{Da}$ in Fig. 1 corresponds to the structure<smiles>COc1cc(C(O)C(CO)Oc2c(OC)cc(/C=C/CO)cc2OC)ccc1O</smiles> 
and the H- $\beta 1-G$ peak at 296 Da corresponds to the structure

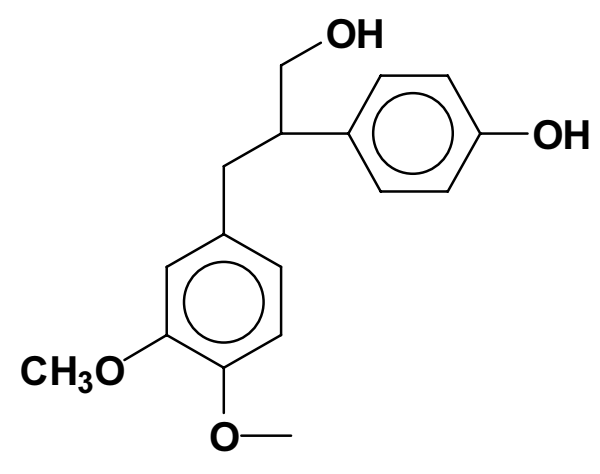

The ${ }^{13} \mathrm{C}$ NMR analysis confirms the similarity of the two lignins: in Fig. 2 the NMR spectra show that differences between the two lignins exist but that they are rather small. Thus, in Fig. 2 the band at 55 ppm characteristic of the methoxy groups $\left(-\mathrm{OCH}_{3}\right)$ of lignin bound to the aromatic ring is slightly less intense for the purified lignin. As this was purified at $50^{\circ}-60^{\circ} \mathrm{C}$ some demethoxylation has occurred which is a very common reaction in lignin (Fengel and Wegener 1983). Equally, the higher relative proportion of acetic/formic esters in purified lignin are different as shown by the peaks at 21 and 30 $\mathrm{ppm}$ of the carbon of the methyl group $-\mathrm{CH}_{3}$ of the acetic acid esters and free acetic acid carboxyl ion, respectively, and the less noticeable increase of the $\mathrm{C}=\mathrm{O}$ peak of the formic acid esters at $161 \mathrm{ppm}$ and of the free formic acid carboxyl ion at $172 \mathrm{ppm}$. These small differences in ester content are relative to the higher purity of purified lignin.

The results of the thermo-mechanical analysis indicate that the purified organosolv lignin gives higher Modulus of Elasticity (MOE) values than the non-purified one (Fig. 3). However, the result is low only in appearance. In reality, the impurities present in the non-purified lignin decrease the amount of actual binding material on the beech lamina in the TMA tests. Such a slightly lower amount of actual binding resin yields a lower TMA max MOE value result for the non-purified lignin due to the well known effect TMA has to exaggerate the differences in results (Pizzi et al. 2003, Zanetti et al. 2004). That this is indeed the case is shown by the results of actual wood panels bonded with these adhesives (Tables 4 and 5). The MOE starts to decrease after $170^{\circ} \mathrm{C}$ on the TMA diagrams (Fig. 3) due to the start of the degradation of wood constituents, as previously shown (Kamoun et al. 1998). This does not affect board strength as at the very short press times used for panel manufacture the max temperature reached in the board core, which determines IB strength, does not reach a temperature higher than $120^{\circ} \mathrm{C}$.

The results for wood particleboard prepared with the mixed formulations of tannin/hexamine +glyoxalated lignin are shown in Table 4. The internal bond (I.B.) strength of a panel is a direct measure of the performance of the adhesive. The results in Table 4 indicate that no significant difference exists as regards internal bond (I.B.) strength of the panels prepared using the two lignins according to relevant interior panel standards (EN 312). When the two resins are mixed 50/50 by weight solids content to solids content, the results are enough to satisfy international standard requirements for interior grade boards (Table 4). However, a decrease in the relative proportion of tannin/hexamine entails a rapid decrease in the IB strength of the panels (Table 4). Because the panel at tannin: lignin $=40: 60$ has an IB strength equal to the minimum value required by the standard, the indications are that to use formulations where the amount of tannin is less that around $45 \%$ of the total would be unfeasible at industrial level. One consideration of particular interest is that the results obtained with the non-purified lignin are comparable and equally good as those of the formulations using the purified one. This is a considerable advantage as the unpurified, unwashed lignin is considerably cheaper to produce. 
The results for the two types of plywood, $6 \mathrm{~mm}$ thick standard beech plywood and $14 \mathrm{~mm}$ thick flooring type mixed veneers plywood are reported in Table 5. The European Standard EN314-2 for interior grade plywood specifies that the percentage wood failure and dry tensile strength obtained by testing of the panel are to be evaluated on a reciprocal sliding scale. Thus, the percentage wood failure for dry tensile strength can be of $0 \%$ for any strength results $\geq 1.0 \mathrm{MPa}$. Equally, if the dry tensile strength is higher than $0.6 \mathrm{MPa}$ but lower than $1.0 \mathrm{MPa}$ the percentage wood failure required is $\geq 40 \%$. The results in Table 4 indicate that both plywoods pass well such a standard requirement, and that the tensile value of tannin/lignin bonded panel is only slightly lower than what was obtained with the tannin alone.

It is of interest to understand the main mechanisms according to which the formulation works. As lignin is of much lower reactivity than flavonoid tannin, a series of parallel reactions occurs to yield coreaction of tannin with lignin. Thus, tannin reacts very rapidly in the hot press with hexamine to form a network based on the known reactions of tannin with hexamine (Kamoun and Pizzi 2000a,b; Pichelin et al. 2006). Lignin, much slower, is prereacted in a reactor with glyoxal (Lei et al. 2008, Pizzi 2006). Although some condensation of glyoxalated lignin occurs during the reaction, that if the reaction is protracted for longer times will increase unduly the viscosity of the glyoxalated lignin, condensation needs to be minimized and addition of glyoxal on the lignin maximized. The glyoxalated lignin is then rich in methylol-type groups obtained by glyoxal addition, but the aromatic nuclei of lignin are still too slow for glyoxalated lignin alone to condense to a sufficiently hardened network in just the very brief period the board remains in the hot press. The methylol-type groups obtained by glyoxal addition to lignin are then forced to react with the much more reactive flavonoid tannin introducing then the lignin in the final copolymer network. A simplified scheme explaining in brief the reactions involved is shown in Fig. 4.

In Table 4 the decrease of board IB strength when decreasing the relative proportion of tannin in the formulation is then due to the decrease of the reactive sites in which the glyoxalated lignin can react in the brief period the panel is in the hot press. In the hot press, the max temperature reached in the board core does not reach a temperature higher than $120^{\circ} \mathrm{C}$ rendering the reaction even more sensitive to reagents proportions. It is not excluded that varying glyoxalation level and times of the lignin the proportion of tannin could be somewhat decreased but the correct conditions to achieve this have not been explored as yet.

\section{CONCLUSION}

For the first time, mixed wood panel adhesive formulations for interior-grade applications were developed in which lignin is in considerable proportion, $50 \%$, of the wood panel binder and in which no "fortification" with synthetic resins, such as isocyanates and phenol-formaldehyde resins used in the past, is necessary to obtain results satisfying relevant standards. Furthermore, environmentfriendly, non-toxic polymeric materials of natural origin constitute as much as $94 \%$ of the total panel binder formulation. The wood panel itself is then constituted of $99.5 \%$ natural materials. The $0.5 \%$ non natural material is composed of glyoxal, a non toxic and non volatile aldehyde, and of hexamine that has already been proven and accepted as a non-formaldehyde-yielding compound when in presence of a condensed tannin adhesive (Pichelin et al. 2006). As for the tannin/hexamine binders alone these panels also present an effective zero formaldehyde emission when tested by the dessicator method (JIS A5908).

\section{REFERENCES}

Amaral-Labat GA, Pizzi A, Goncalves AR, Celzard A, Rigolet S (2008) Environment-friendly soy flour-based resins without formaldehyde. J Appl Polym Sci 108: 624-632.

Avignon G, Delmas M (2000) Method for producing paper pulp, lignins, sugars and acetic acid by frantionation of lignocellulosic vegetable material in formic/acetic acid medium. US patent $7,402,224$ 
Ballerini A, Despres A, Pizzi A (2005) Non-toxic, zero-emission tannin-glyoxal adhesives for wood panels. Holz Roh Werkst 63: 477-478

Despres A, Pizzi A (2006) Colloidal aggregation of aminoplastic polycondensation resins: UF vs. MF and MUF resins, J.Appl.Polym.Sci., 100: 1406-1412

El Mansouri N-E, Pizzi A, Salvado' J (2007) Lignin-based wood panel adhesives without formaldehyde. Holz Roh Werkst 65: 65-70.

EN 312 (1995) Wood particleboard - specifications

EN 314-2 (1993) Plywood - specifications

Fengel D, Wegener G (1983) Wood: chemistry, ultrastructure, reactions. Walther De Gruyter, Berlin

Hillis WE, Urbach G (1959) Reaction of polyphenols with formaldehyde. J Appl Chem 9: 665-673.

JIS A5908 (1994) Particleboards, Japanese Standards Assoc., Tokyo, Japan

Kamoun C, Pizzi A (2000a) Mechanism of hexamine as a non-aldehyde polycondensation hardener, Part 1: mechanisms. Holzforsch. Holzverw. 52: 16-19.

Kamoun C, Pizzi A (2000b) Mechanism of hexamine as a non-aldehyde polycondensation hardener, Part 2: recomposition of intermediate reactive compound. Holzforsch Holzverw 52: 66-67.

Kamoun C, Pizzi A, Garcia R (1998) The effect of humidity on cross-linked and entanglement networking of formaldehyde-based wood adhesives. Holz Roh Werkst 56: 235-243.

Kamoun C, Pizzi A, Zanetti M (2003) Upgrasing of MUF resins by buffering additives - Part 1:

hexamine sulphate effect and its limits, J.Appl.Polymer Sci., 90(1): 203-214

Lei H, Pizzi A, Du G (2008) Environment-friendly, mixed tannin/lignin wood resins. J Appl Polym Sci 107: 203-209.

Lorenz L, Frihart CR, Wescott JM (2006) Analysis of soy flour/phenol-formaldehyde adhesives for bonding wood, Proceedings Wood Adhesives 2005, Forest Products Society, Madison Wisconsin, pp. 501-506

NIOSH (2000), National Institute for Occupational Safety and Health, The Registry of Toxic Effects of Chemical Substances, December 2000

NTIS** - National Technical Information Service. (Springfield, VA 22161) Formerly U.S.Clearinghouse for Scientific \& Technical Information. AD-A125-539

Pichelin F, Nakatani M, Pizzi A, Wieland S, Despres A, Rigolet S (2006) Thick wood panels bonded industrially with formaldehyde free tannin adhesives. Forest Prod J 56: 31-36.

Pizzi A (1978) Tannin formaldehyde exterior wood adhesives through flavonoid B-ring cross-linking. J Appl Polym Sci 22: 2397-2399.

Pizzi A (2006) Developments in biobased adhesives for wood bonding: opportunities and issues. J Adhesion Sci Technol 20: 829 - 846.

Pizzi A, Beaujean M, Zhao C, Properzi M, Huang Z (2003) Acetals-induced strength increase and lower resin contents in MUF and PF wood adhesives Holz Roh- Werkst 61: 419-422.

Pizzi A, Stephanou A (1993a) Rapid curing lignins-based exterior wood adhesives, Part 1: diisocyanates reaction mechanisms and application to panel products. Holzforschung 47: 439-445.

Pizzi A, Stephanou A (1993b) Rapid curing lignins-based exterior wood adhesives, Part 2: Acceleration mechanisms and application to panel products. Holzforschung 47: 501-506.

Roux, D (1976) Wattle bark and Mimosa extract, Leather Industries Research Institute, Grahamstown, South Africa

Suomi-Lindberg L (1985) Bark extracts and their use in plywood bonding. Paperi Ja Puu 67(2): 65-69.

Stiasny E (1905a) The action of formaldehyde on the tannins. Der Gerber 740: 186.

Stiasny E (1905b) The action of formaldehyde on the tannins. Der Gerber 775: 347.

Theis M, Grohe B (2002) Biodegradable lightweight construction boards based on tannin/hexamine bonded hemp shaves. Holz Roh- Werkst 60: 291-296.

Wescott JM, Frihart CR, Lorenz L (2006) Durable soy-based adhesive dispersions, Proceedings Wood Adhesives 2005, Forest Products Society, Madison Wisconsin, pp. 263-270.

Zakis, GF (1994) Functional Analysis of Lignins and Their Derivatives.Tappi p 65.

Zanetti M, Pizzi A, Faucher P (2004) Low-volatility acetals to upgrade the performance of MUF wood adhesives J Appl Polym Sci 92: 672-675.

Zhao C, Pizzi A, Kühn A, Garnier S (1999) Fast advancement and hardening acceleration of low condensation alkaline PF resins by esters and copolymerized urea. J Appl Polym Sci 74: 359378 
Ejwwp423_source

Table 1. Characteristics of wheat straw organosolv lignin

\begin{tabular}{llccc}
\hline & $\begin{array}{c}\text { Formyl } \\
(\mathrm{mmol} / \mathrm{g})\end{array}$ & $\begin{array}{c}\text { Acetyl } \\
(\mathrm{mmol} / \mathrm{g})\end{array}$ & $\begin{array}{c}\text { Free Hydroxyls } \\
(\mathrm{mmol} / \mathrm{g})\end{array}$ & $\begin{array}{c}\text { Total } \\
(\mathrm{mmol} / \mathrm{g})\end{array}$ \\
\hline Total -OH groups & 0.6 & 0.5 & 2.90 & 4.00 \\
Phenolic -OH groups & 0.20 & 0.05 & 0.85 & 1.10 \\
Aliphatic -OH groups & 0.40 & 0.45 & 2.05 & 2.90 \\
\hline
\end{tabular}

Table 2. Characteristics of wheat straw organosolv lignin.

\begin{tabular}{|c|c|c|c|c|c|c|c|c|c|c|}
\hline & \multicolumn{2}{|c|}{ Klason lignin } & \multirow{2}{*}{$\begin{array}{l}\text { Total } \\
\text { lignin } \\
(\%)\end{array}$} & \multirow{2}{*}{$\begin{array}{l}\text { Ashes } \\
(\%)\end{array}$} & \multirow{2}{*}{$\begin{array}{c}\text { Glucan } \\
(\%)\end{array}$} & \multirow{2}{*}{$\begin{array}{l}\text { Xylan } \\
(\%)\end{array}$} & \multirow{2}{*}{$\begin{array}{c}\text { Mannan } \\
(\%)\end{array}$} & \multirow{2}{*}{$\begin{array}{c}\text { Galactan } \\
(\%)\end{array}$} & \multirow{2}{*}{$\begin{array}{c}\text { Arabinan } \\
(\%)\end{array}$} & \multirow{2}{*}{$\begin{array}{l}\text { Total } \\
\text { without } \\
\text { glucan } \\
(\%)\end{array}$} \\
\hline & $\begin{array}{c}\text { insoluble } \\
(\%)\end{array}$ & $\begin{array}{c}\text { soluble } \\
(\%)\end{array}$ & & & & & & & & \\
\hline Non-purif. & 79.3 & 3.1 & 82.4 & 3.49 & 5.57 & 5.80 & 0.15 & 1.01 & 1.58 & 8.54 \\
\hline Purified & 82.7 & 2.22 & 84.9 & 1.83 & 4.49 & 5.98 & 0.38 & 0.97 & 1.45 & 8.78 \\
\hline
\end{tabular}

Table 4. Particleboard bonded with tannin/lignin adhesives. Results

\begin{tabular}{llc}
\hline \multicolumn{1}{c}{ Proportion } & $\begin{array}{c}\text { Density } \\
\left(\mathrm{kg} / \mathrm{m}^{3}\right)\end{array}$ & $\begin{array}{c}\text { Dry I.B. strength } \\
(\mathrm{MPa})\end{array}$ \\
$\begin{array}{c}\text { Tannin/hexamine+ } \\
\quad+\text { glyoxalated lignin(non-purified) } 50 / 50\end{array}$ & 702 & $0.52 \pm 0.05$ \\
$\begin{array}{c}\text { Tannin/hexamine+ } \\
\quad+\text { glyoxalated lignin(purified) } 50 / 50\end{array}$ & 700 & $0.45 \pm 0.04$ \\
$\begin{array}{c}\text { Tannin/hexamine+ } \\
+ \text { glyoxalated lignin(non-purified) } 40 / 60\end{array}$ & 710 & $0.35 \pm 0.04$ \\
$\begin{array}{c}\text { Tannin/hexamine+ } \\
\quad+\text { glyoxalated lignin(non-purified) } 30 / 70\end{array}$ & 700 & $0.18 \pm 0.03$ \\
European Norm EN 314-2 requirement & & $\geq 0.35$ \\
\hline
\end{tabular}


Ejwwp423_source

Table 5. Plywood bonded with tannin/lignin adhesives. Results

$\begin{array}{ccc}\text { Proportions } & \begin{array}{c}\text { Dry Tensile Strength } \\ (\mathrm{MPa})\end{array} & \begin{array}{c}\text { Wood failure } \\ (\%)\end{array}\end{array}$

\section{Beech Plywood}

Control Tannin/hexamine

100

$1.4+0.10$

0

Tannin/hexamine+

+ glyoxalated lignin(non-purified)

$50 / 50$

$1.2+0.20$

10

Thick floor plywood

Tannin/hexamine +

+ glyoxalated lignin(non-purified)

$50 / 50$

$1.0 \pm 0.19$

46

EN314-2 requirements

$\begin{array}{cc}\text { if } \geq 1.0 \text { then } & \text { No requirement } \\ \text { if } 0.6 \leq \text { and }<1.0 \text { then } & \geq 40\end{array}$




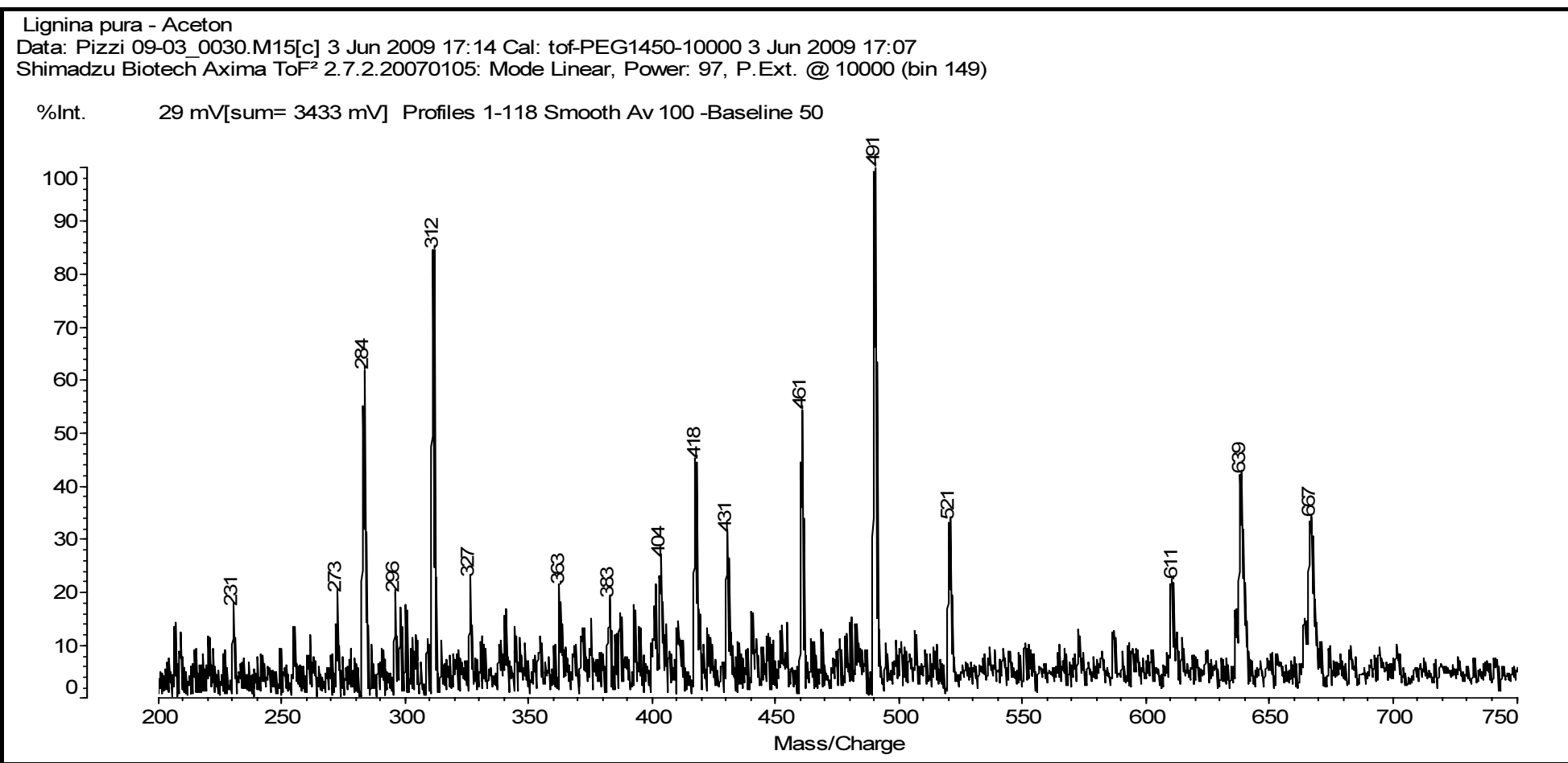

Fig. 1 


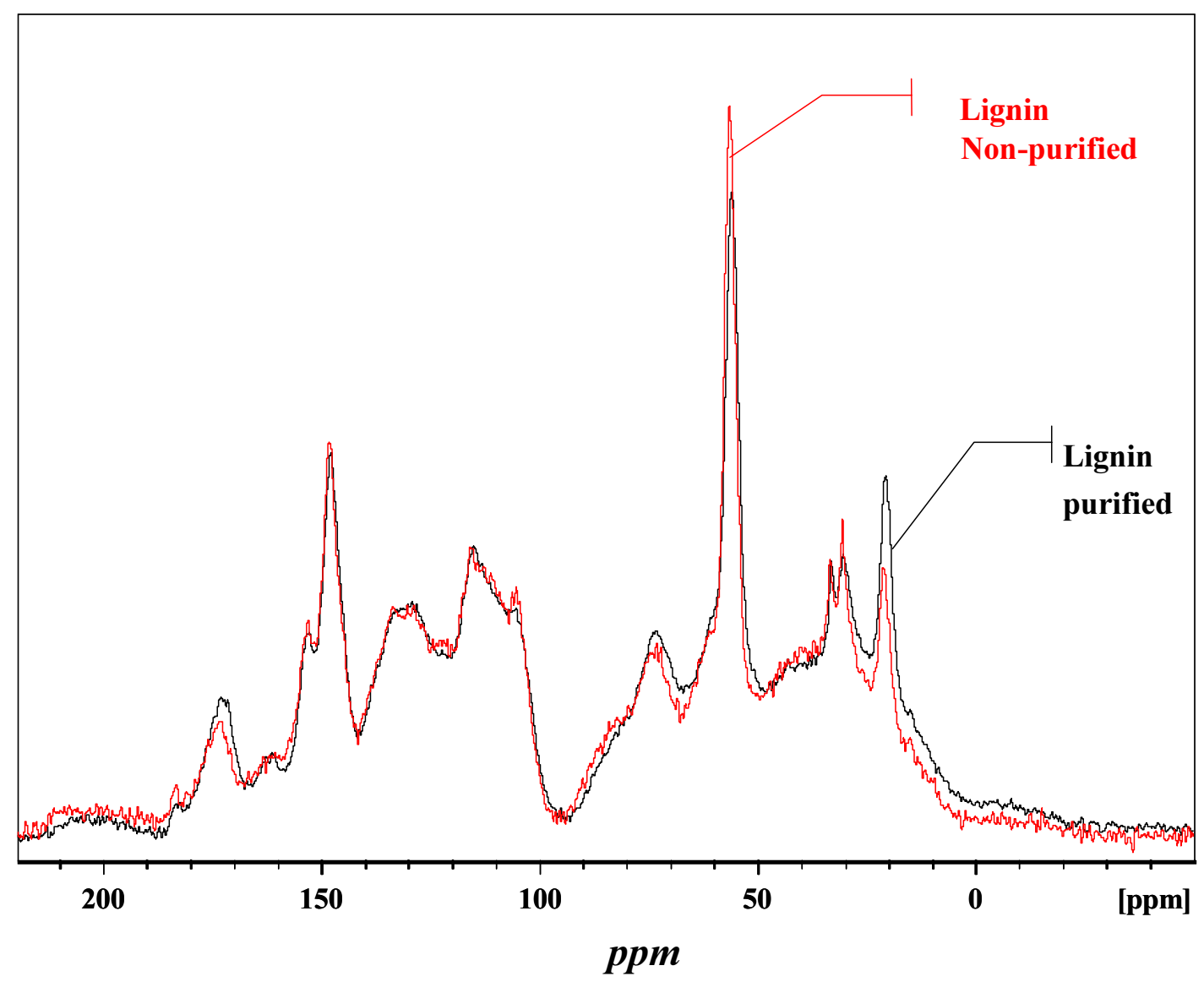

Fig. 2

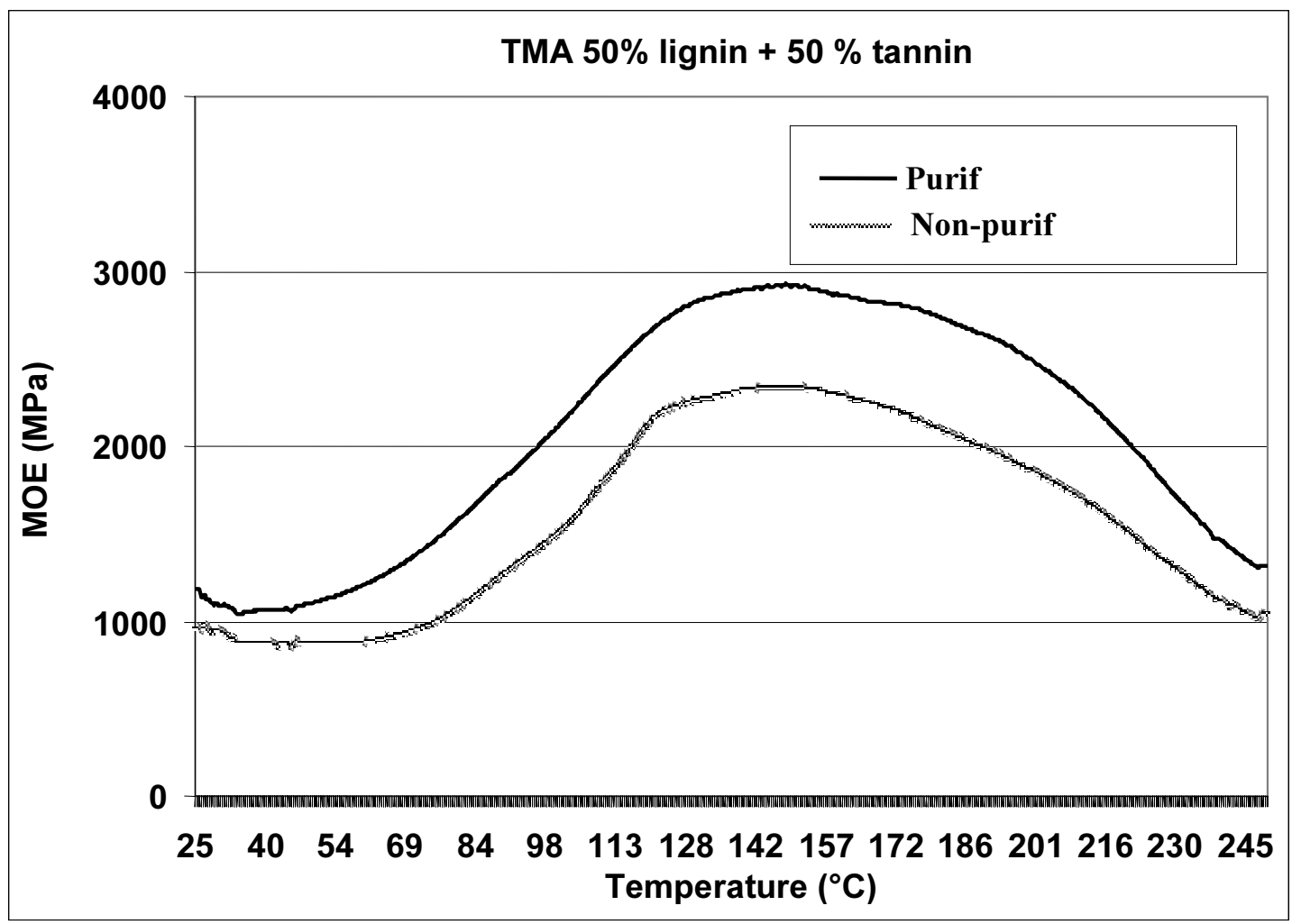

Fig. 3 

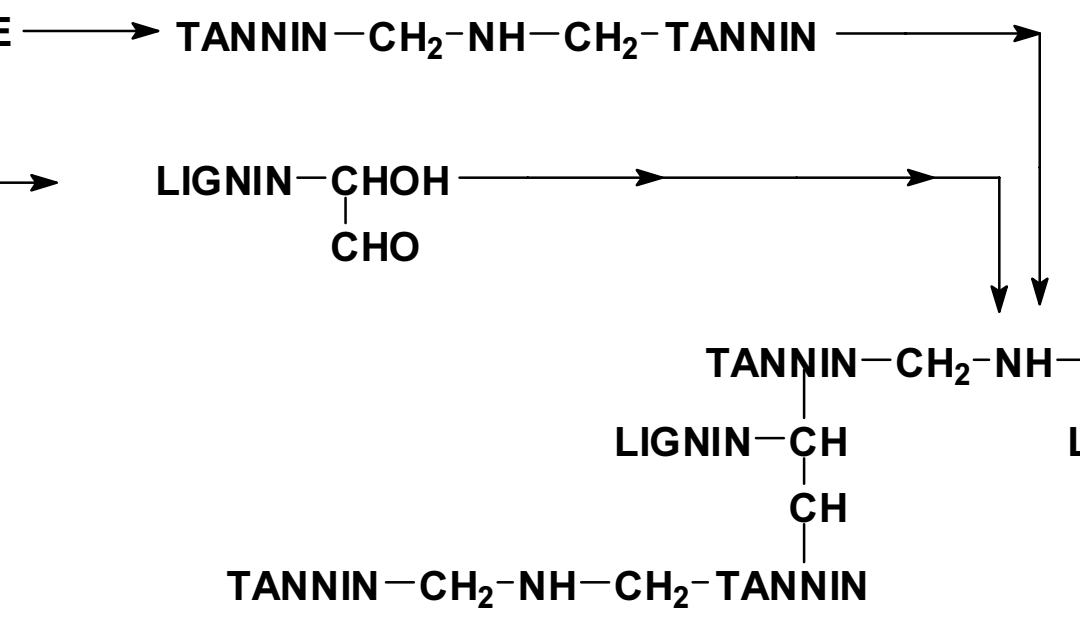

LIGNIN$\mathrm{CH}$ $-\mathrm{CH}_{2}$-TANNIN<smiles>[14CH3]N[GeH3]</smiles>
CH-LIGNIN

FIG. 4

\section{FIGURE LEGENDS}

Fig. 1. MALDI-TOF mass spectrum in the 200-700 Da range indicating the main oligomers distribution in the low molecular weight organosolv lignin used.

Fig. 2. Comparative CP-MAS ${ }^{13} \mathrm{C}$ NMR spectra of purified and non-purified organosolv lignin derived from formic acid/acedic acid wheat straw pulping.

Fig. 3. Comparison of thermo-mechanical analysis curing curves of beech wood joints bonded with tannin/lignin 50/50 wood adhesives. Variation of the joint MOE as a function of temperature.

Fig. 4. Schematic representation of the series of reactions occurring in the formation of the tannin/lignin hardened network of the formulation.

Tabelle 1

Eigenschaften des Organosolv-Lignins aus Weizenstroh

Tabelle 2

Eigenschaften des Organosolv-Lignins aus Weizenstroh

Tabelle 3

Mittels MALDI-TOF Massenspektrometrie bestimmte Verteilung der Oligomere in dem für den Klebstoff verwendeten Organosolv-Lignin

Tabelle 4

Eigenschaften der mit Tannin/Lignin-Klebstoffen hergestellten Spanplatten

\section{Tabelle 5}

Eigenschaften der mit Tannin/Lignin-Klebstoffen hergestellten Sperrholzplatten

Abb. 1 
MALDI-TOF Massenspektrum im Bereich von 200-700 Da, das die Verteilung der Hauptoligomere im verwendeten niedermolekularen Organosolv-Lignin zeigt

Abb. 2

Vergleichende CP-MAS ${ }^{13}$ C NMR Spektren von gereinigtem und nicht gereinigtem Organosolv-Lignin aus Essigsäure-/Ameisensäureaufschluss von Weizenstroh

Abb. 3

Vergleich der Ergebnisse einer thermomechanischen Analyse von Buchenholzverbindungen, die mit Tannin/Lignin (50/50) Klebstoffen verklebt wurden. Variation des E-Moduls der Verbindung in Abhängigkeit der Temperatur.

Abb. 4

Schematische Darstellung der Reaktionen beim Aushärten des Tannin/Lignin-Klebstoffes

Table 3. MALDI-TOF derived distribution of oligomers in the organosolv lignin used for the adhesive.

\begin{tabular}{|c|c|c|c|c|c|}
\hline & Structure & $\begin{array}{c}\text { Calculated } \\
\text { M.W. }\end{array}$ & $\begin{array}{l}\text { Calculated } \\
\text { M.W.+Na }\end{array}$ & $\begin{array}{c}\text { Experimental } \\
\text { peak }\end{array}$ & $\begin{array}{c}\text { Peak relative } \\
\text { proportion }(\%)\end{array}$ \\
\hline \multirow[t]{2}{*}{$\mathrm{S}$} & monomer & 210 & 233 & 231 & 18 \\
\hline & & & & 273 & \\
\hline $\begin{array}{l}\mathrm{H}-\beta 1-\mathrm{H}- \\
-1 \mathrm{x}-\mathrm{OH}\end{array}$ & dimer & 261 & 284 & 284 & 63 \\
\hline $\begin{array}{l}\mathrm{H}-\beta 1-\mathrm{G} \\
\mathrm{G}-\beta 1-\mathrm{H}\end{array}$ & dimers & 273 & 296 & 296 & 18 \\
\hline $\begin{array}{l}326-1 x-\mathrm{CH}_{2}- \\
\text { (demethylation) }\end{array}$ & dimers & 289 & 312 & 312 & 85 \\
\hline $\begin{array}{l}H-\beta 1-S \\
G-\beta 1-G \\
S-\beta 1-H\end{array}$ & dimers & 303 & 326 & 327 & 22 \\
\hline $\begin{array}{l}\mathrm{H}-\beta \mathrm{O} 4-\mathrm{S} \\
\mathrm{G}-\beta \mathrm{O} 4-\mathrm{G} \\
\mathrm{S}-\beta \mathrm{O} 4-\mathrm{H}\end{array}$ & dimers & 360 & 360 & 383 & 18 \\
\hline $\begin{array}{l}G-\beta \beta-G \\
G-\beta 5-G\end{array}$ & dimers & 394.4 & 417.4 & 418 & 43 \\
\hline
\end{tabular}


Ejwwp423_source

\begin{tabular}{|c|c|c|c|c|c|}
\hline \multicolumn{6}{|l|}{ G-55'-G } \\
\hline $\begin{array}{l}\text { G- } \beta \mathrm{O} 4-\mathrm{S} \\
\mathrm{G}-\alpha \mathrm{O} 4-\mathrm{S}\end{array}$ & dimers & 407 & 430 & 431 & 32 \\
\hline $\begin{array}{l}\text { S- } \beta O 4-S \\
\text { S- } \alpha O 4-S\end{array}$ & dimers & 437 & 460 & 461 & 54 \\
\hline \multirow[t]{2}{*}{$\begin{array}{l}\mathrm{S}-\beta \mathrm{O} 4-\mathrm{S}+2 \mathrm{x}- \\
\mathrm{OH} \\
\mathrm{S}-\alpha \mathrm{O} 4-\mathrm{S}+2 \mathrm{x}- \\
\mathrm{OH}\end{array}$} & dimers & 468 & 491 & 491 & 100 \\
\hline & & & & 521 & \\
\hline $\begin{array}{l}\text { S- } \beta \text { O4-S- } \beta \beta-\mathrm{H} \\
\text { G- } \beta \mathrm{O} 4-\mathrm{G}-\beta \beta-\mathrm{S} \\
\mathrm{G}-\beta \mathrm{O} 4-\mathrm{G}-\beta 5-\mathrm{S} \\
\mathrm{G}-\beta \mathrm{O} 4-\mathrm{S}-55^{\prime}-\mathrm{G}\end{array}$ & trimers & 585 & 608 & 611 & 21 \\
\hline $\begin{array}{l}\text { G- } \beta \mathrm{O} 4-\mathrm{S}-\beta \beta-\mathrm{S} \\
\text { G- } \beta \mathrm{O} 4-\mathrm{S}-\beta 5-\mathrm{S} \\
\mathrm{G}-\beta \mathrm{O} 4-\mathrm{S}-55^{\prime}-\mathrm{S}\end{array}$ & trimers & 615 & 638 & 639 & 40 \\
\hline $\begin{array}{l}\text { S- } \beta O 4-S-\beta \beta-S \\
\text { S- } \beta O 4-S-\beta 5-S \\
\text { S- } \beta O 4-S-55 \text { '-S }\end{array}$ & trimers & 644.7 & 667.7 & 667 & 34 \\
\hline
\end{tabular}

